\title{
INTEGRATING HYBRIDITY AND BUSINESS MODEL THEORY IN SUSTAINABLE ENTREPRENEURSHIP
}

Accepted in Journal of Cleaner Production

\author{
Dr. Iain A. Davies ${ }^{\mathrm{a}^{*}} \&$ Dr. Liudmila Chambers ${ }^{\mathrm{b}}$ \\ ${ }^{a}$ University of Bath School of Management, Claverton Down Road, Bath, UK, BA2 7AY, Tel: \\ +44 (0) 122538 6839, Email: 1.davies@,bath.ac.uk; Liudmila.chambers@gmail.com \\ b Verisk Maplecroft, 1 Henry St, Bath, UK, BA1 1JS, Tel: +44 (0) 1225 420000, Email: \\ Liudmila.chambers@gmail.com
}

* For Correspondence: Iain A. Davies, Senior Lecturer in Marketing, University of Bath School of Management, Tel: +44 (0) 122538 6839, Email: i.davies@,bath.ac.uk

Abstract

This paper investigates the means by which business model innovations help mitigate hybrid tensions in sustainable entrepreneurs. By integrating the sustainable business models, and hybrid entrepreneurship literature it highlights the overlap between the discourses in these fields. An in-depth exploration of ten sustainable entrepreneurs then demonstrates common business model innovation to ameliorated hybridity related tensions.

\subsection{Introduction}

There is growing interest in harnessing entrepreneurial competencies to address social, environmental and economic aspects of sustainable development (Schaltegger and Wagner, 2011; Schaltegger et al., 2016). Yet research in this area identifies managerial tensions driven by the multiple types of value sustainability focused entrepreneurs are trying to create (Battilana and Lee, 2014; Pache and Santos, 2013). Hybrid organizational theory has therefore become prevalent in exploring how pro-social and environmental value manifests alongside economic value in entrepreneurial organizations (Battilana and Dorado 2010; Doherty et al., 2014). Failure to manage tensions between these types of value is identified as leading to mission-drift, where the economic value typically becomes dominant over social and environmental value (Ebrahim et al., 2014). The literature therefore presents contestation and tension as the norm in sustainability focused entrepreneurs. 
In contrast to the hybridity literature, the sustainable business models literature suggests holistic models of sustainable entrepreneurship can exist, where the social, environmental, and economic value can be mutually-supportive (Lans et al., 2014; Schaltegger et al., 2016).

However, the sustainable business models literature typically explores businesses transitioning towards sustainability (Boons and Lüdeke-Freund, 2013; Schaltegger et al., 2012), with limited studies looking at organizations set-up with multiple types of value creation at their core (Bocken et al., 2016; Rauter et al., 2017). This paper therefore contributes to the field by empirically exploring business model innovations, which help mitigate hybrid tensions, from ten sustainable entrepreneurs. In so doing we promote the notion of holistic hybrid business models as a key mechanism for sustainable value capture.

\subsection{Literature review}

The following section defines sustainable entrepreneurship and its relationship to other types of sustainability focused entrepreneurs. This leads us to explore value creation and tensions in hybrid entrepreneurs, and the emergence of sustainable business models in facilitating multiple forms of value creation. We then explore the intersection between sustainable business models and hybridity.

\subsubsection{Sustainable entrepreneurship}

Harnessing entrepreneurial capability to address sustainable development has come to be termed sustainable entrepreneurship (Schaltegger and Wagner, 2011). Although sustainability is a contested concept, sustainable entrepreneurship focuses on the identification of new business opportunities which result in more sustainable products, or processes, than currently available on the market (Deans and McMullen, 2007; Schaltegger et al., 2016). Lüdeke-Freund et al. (2017) identifies these sustainable entrepreneurs making a voluntary commitment to create social and 
environmental value, beyond that of a conventional business venture, whilst simultaneously creating economic value. This however creates the potential for tension between these different forms of value creation.

There are clear parallels between sustainable entrepreneurship and other sustainability focused entrepreneurs, such as social entrepreneurship and social enterprise, where organizations are dealing with the tensions associated with the creation of multiple types of value (Defourny and Nyssens 2012; Schaltegger and Wagner, 2011). Indeed many organizations could simultaneously fall under multiple definitions across these fields. Deans and McMullen (2007) suggest sustainable entrepreneurs diverge from social entrepreneurs in that they address profitdriven opportunities rather than mission-driven ones. However, this belies the potential for sustainable entrepreneurs to be mission-driven, as discussed by Schaltegger and Wagner (2011), Hall et al. (2010), and Jolink and Niesten, (2015). The European Commission (2017) defines social enterprises as organizations which "combine societal goals with entrepreneurial spirit" focused on "achieving wider social, environmental or community objectives", which itself is convergent with definitions of sustainable entrepreneurship (Lüdeke-Freund et al., 2017; Schaltegger et al., 2016). The European Commission also identifies social enterprises as having profit as a secondary focus, which reinvest rather than distribute profits. This could be the case for sustainable entrepreneurs, but not always (Jolink and Niesten, 2015; Lan et al. 2014). To fully situate sustainable entrepreneurship, definitions suggest they are reliant on earned income (Deans and MuMullen, 2007, Schaltegger and Wagner 2011), which is not necessarily the case for social enterprises (Defourny and Nyssens 2012). They would also fall under the definition of integrated hybrids, in that their social and environmental impact is often served through their 
customer value creation, as opposed to differentiated hybrids when beneficiary and customer value are not simultaneously created (Battilana et al., 2012; Ebrahim et al., 2014).

Despite different terminology, scholars across disciplines are converging on the idea that sustainability focused entrepreneurs are hybrid organizations, targeting multiple forms of value creation (Lan et al., 2014; Grassl, 2012). Hybridity is premised on the assumption that norms at a societal level; called logics, shape beliefs and behavior at an organizational level (DiMaggio and Powell, 1983). Where multiple logics are in play; such as commercial vs. sustainable logics, tensions, and contestation are common (Greenwood et al., 2010; Pache and Santos, 2010). Despite limited work integrating business models and sustainability focused entrepreneurs (Lüdeke-Freund et al., 2017; Margiono et al., 2017), organizational responses to these hybrid tensions can be documented through the components of sustainable business models.

\subsubsection{Sustainable Business Models}

Sustainable business models literature would suggest that sustainable entrepreneurs can holistically create economic, social and environmental value (Baumgartner and Ebner, 2010; Lüdeke-Freund et al., 2017). Although the definitions of business models vary (Boons and Lüdeke-Freund, 2013; Osterwalder et al., 2005), this paper identifies them as the organizational architecture that sits between strategy and activities, forming the basis for competitive positioning (Teece, 2010).

Osterwalder et al., (2005) defined four pillars of business models, broken down into nine building blocks. Subsequent revisions such as Bocken et al., (2014) and Osterwalder and Pigneur (2010), have consolidated these to the core elements of the value proposition, value creation and delivery, and value capture. According to Bocken et al. (2014) value propositions relate to the product-service system developed by a business, its target customers, and the types of existing 
customer relationships; value creation and delivery relate to the key organizational activities which develop the market offering, plus the resource acquisition, channel management, partner management and use of technology; lastly value capture relates to the revenue streams and cost structures of the enterprise. Although operating as a summary of the overall business models approach, these three elements facilitate cross-comparison to disperse fields of research as shown by Bocken et al. (2014), and form the foundation for this papers integration with the hybridity literature.

Despite early work on business models focusing on economic value creation (Teece, 2010), scholars have recently identified business models as a core component in embedding sustainability into organizations (Bocken et al., 2014; Rauter et al., 2017). The term sustainable business model innovation is then applied to the process of transforming/creating, business models able to balance economic, social, and environmental value creation, and thus mitigate hybrid tensions (Boons and Lüdeke-Freund, 2013). However recent calls highlight the scarcity of empirical evidence in this space, and the lack theory into how business models can be used to create and capture multiple forms of value in sustainable entrepreneurs (Lüdeke-Freund et al., 2017; Margiono et al., 2017).

Boons and Lüdeke-Freund (2013) present three streams of sustainable business models literature, of relevance to sustainable entrepreneurs. The first explores the development of cleaner technologies, with the potential to reshape markets. The second explores organizational form, culture, and routines, aimed at more sustainable business practices. The third deals with social innovation, and in particular how sustainable entrepreneurs create social and environmental impact alongside operational profit. Bocken et al. (2014) take this further by proposing architype business models which sit within these three research streams (see Bocken 
et al. 2014). The common underpinning of each architype is that building a robust business model is essential to achieving economic, social and environmental value creation objectives (Baumgartner, 2009; Bocken et al., 2016).

Interestingly, the sustainable business models literature (in stark contrast to the hybridity literature) rarely identifies tensions between types of value creation, or addresses how businesses can ameliorate hybrid tensions (Lüdeke-Freund et al., 2017). Normative papers such as Boons and Lüdeke-Freund (2013) and Bocken et al. (2014) draw on sustainable entrepreneurship examples in categorizing the business model field, and Grassl (2012) and Margiono et al. (2017) both provides typologies of sustainable entrepreneurship business models, but don't directly address tensions. Conversely others such as Hahn and Ince (2016) and Wilson and Post (2013) use the term business model generically whilst exploring hybrid tensions, but without reference to the theoretical domain. Schaltegger et al. (2016) and Bocken et al. (2016) provides rare exceptions in that they explicitly identify how sustainable entrepreneurial business models can create multiple forms of value, but don't link this to hybridity debates. Thus this paper provides an original contribution through the intersection of these two fields.

\subsubsection{Components of hybrid business models}

Business model innovations to cope with organizational hybridity are often found implicitly within literatures exploring governance (Battilana and Lee, 2014), organizational management (Doherty et al., 2014), and external interactions (Moss et al., 2011) of sustainability focused entrepreneurs. Social enterprises are not, however, universally successful in managing hybrid tensions, with mission drift (Pache and Santos, 2010) and a lack of stakeholder legitimacy (Nicholls, 2010) commonly reported. Exploring the core elements of business models, in relation to managing tensions, however, reveals a great deal of the similarity between the fields. Table 1 
presents the intersection of hybrid organizing and business model research. Due to the lack of papers on sustainable entrepreneurship, the dimensions of hybrid organizing are presented from five explorations from within the social enterprise literature (Battilana and Lee, 2014; Dacin, et al., 2011; Doherty, et al., 2014; Moss et al., 2011; Hahn and Ince, 2016). The first three are review papers on tensions caused by hybridity, and the other two are empirical papers looking for markers of hybridity within social enterprise populations. These represent an indication of the intersection, rather than as an exhaustive coverage of the field.

\section{[Insert Table 1Here]}

Value Propositions: Despite being considered the key leverage for transforming business models (Osterwalder et al., 2014), value propositions are under-explored in sustainability focus entrepreneurs. Austin et al., (2006), Hahn and Ince (2016), and Moss et al., (2011) all discuss integrating the multiple dimensions of hybridity into value propositions, to communicate social value to stakeholders. However Dey and Teasdale (2016) suggest the opposite, that enterprises must strategical manipulate their propositions for different stakeholders, due to the complexity of hybrid messages creating confusion. However, there is limited exploration of how to overcome this within any of the relevant literatures.

Value Creation and Delivery: hybridity literature identifies major hybrid tensions in external resource acquisition and internal operations, including acquiring network, human and financial capital, and access to markets and supply.

- Networks between organizations and people are identified as the bedrock of commercial entrepreneurialism, but there is a lack of research into networks in sustainability focus entrepreneurs. Dacin et al. (2011), point towards three areas of networking which have relevance to hybrid enterprise success: the local level with direct stakeholders, the social 
enterprise level through specialist networks like Ashoka, Schwab and Skoll; and social scalability networks which are inter-organizational relationships used for scalability. How organizations inter-relate with these different network actors, the resources accrued, and the impact on value creation are all important to the management of hybrid tensions, but largely understudied (Battilana and Lee, 2014).

- In terms of human capital, hybrid organizations have been identified as having problems finding employees capable of balancing social and economic values (Battilana and Lee, 2014; Doherty et al., 2014). A workforce which shares similar values to their organization are found to be more committed (Battilana and Lee, 2014), but the complexity of hybrid enterprises makes finding a match between employees and employer difficult (Davies and Crane, 2010). However, both Battilana and Lee (2014) and Davies and Crane (2010) suggest hybrids overcome this through employing people with commercial skills, allowing the organizational culture to socialize the sustainable identity.

- Accessing finance from external parties is a core tension for hybrid enterprises (Santos et al. 2015). Financial institutions struggle to understand the value capture aspect of hybrid business models and are reluctant to lend (Austin et al., 2006; Doherty et al., 2014). Emergent forms of financial capital such as social finance and crowdfunding, touted to fill this financial hole (Lehner and Nicholls, 2014), are limited in volume, and preference new rather than existing enterprises (Davies et al., 2017). Hybrid enterprises also struggle at an ideological level with finance, concerned by the economic focus of lenders, and the tension this creates with social and environmental value capture (Battilana and Lee, 2014; Doherty et al., 2014).

- $\quad$ Market access can be similarly problematic for enterprises that do not wish to partner with mainstream retailers, thus limiting economic, social, and environmental value 
creation. In particular, sustainable entrepreneurs which promote social values such as localism, artisanal, or co-operative practices can struggle culturally with mainstream distribution (Davies et al., 2017).

- Supply-chain innovation is often a core differentiator for sustainable entrepreneurs (Dean and McMullen, 2007). But as Anner (2012) highlights, even businesses following simple CSR activities struggle with supply-chain legitimacy, and struggle for available supply which meets sustainability criteria. It also leads to higher costs of supply which need to be offset by higher retail prices as part of the value proposition (Short et al., 2009).

Value Capture: Issues of value capture are also complex in sustainable entrepreneurs because there is a wide range of potential value creation goals, and limited modes of measurement (Lüdeke-Freund et al., 2017). This is further complicated by the extent to which societal value is automatically created alongside economic value (such as selling more sustainable technology), or contingent on other processes outside of economic activities (such as tackling deforestation) (Santos et al. 2015). Sustainable entrepreneurs therefore need to develop business models which can deliver on the commercial stability of the organization, whilst allowing for long-term scaling of impact.

As this analysis shows, the spheres of interest for alleviating hybrid tensions are the same as for developing sustainable business models (Rauter et al., 2017). However, a holistic exploration of the role business models play in alleviating hybridity tensions is lacking. Gebauer et al. (2017) identifies social enterprise, SOIL, as running four, parallel business models to avoid conflict between types of value creation; one for fundraising, two for earned-income, and one for societal impact. Similarly Joyce and Paquin (2016) separate the three types of value creation in their triple layered business model canvas. Conversely both Bocken et al., (2014) and Grassl 
(2012) identify singular business models which address all forms of value creation in a hybridized way. The extent to which sustainable entrepreneurs run parallel vs. hybrid business models is unclear. Nevertheless, the managerial responses to hybrid tensions, and the business model this creates in sustainable entrepreneurs, presents an ideal theoretical space for exploring how business models facilitate multiple forms of value creation. As such this paper address the question of how sustainable entrepreneurs' business models innovate, to overcome hybridity related tensions.

\subsection{Methodology}

The exploratory nature of the research question lends itself to a qualitative multiple case study approach (Eisenhardt and Graebner, 2007). As suggest by Yin (2003) an initial pilot phase to situate the research and explore data collect methods was undertaken, involving telephone conversations with founders of three sustainable entrepreneurs, and a pilot case study with a sustainable foods company. This phase highlighted the importance of respondent storytelling in gaining deep insight into potential tensions and how they can be alleviated (Lounsbury and Glynn, 2001). The main data collection phase then encompassed ten case studies following the data collection procedures refined in the pilot study.

\subsubsection{Case selection}

Cases were purposefully selected from the $\$ 546 \mathrm{bn}$ lifestyles of health and sustainability sector (NMI, 2015). Most organizations in this sector, and all of our cases, conform to both Dean and McMullen (2007) and Schaltegger and Wagner's (2011) definitions of sustainable entrepreneurs. However the chosen cases also conform to the European Commissions (2017) definition of social enterprise, as they reinvest or donate profits to further their sustainability, thus ensuring comparability to the hybridity literature. All cases also conform to the integrated hybrid model, 
where activities related to revenue generation are directly related to social and environmental impact (Ebrahim et al., 2014).

A database of potential cases was compiled using an online search of major industrial associations promoting sustainable lifestyles in Europe. To promote greater comparability, selected companies were all founded between 2000-2010 (to ensure founders were present, but the business models were successful in surviving), and with reference to a dominant sustainability focus in their mission statement. Ideally all the cases would have been from one country to ensure similar institutional environments, but insufficient organizations were located in any one country to achieve this. Therefore we included companies from Western Europe (UK, France, Belgium and Switzerland). 57 enterprises met our criteria and were contacted via email and telephone. Ten of which were able to participate in the timeframe set for the study. More information on them is included in Table 2 .

[Insert table 2 here]

\subsubsection{Data collection}

To capture areas of hybrid tension, and gain deep insight into business model innovation, several key decision-makers from each case were interviewed. When it was not possible, the most influential decision-maker was interviewed. Interviews lasted over an hour, and questions were designed to encouraged respondents to engage in storytelling about the enterprises founding, mission, processes, and activities. Data was also collected from websites, news databases and internal documents to allow for triangulation with interview data (Yin, 2003).

\subsubsection{Data analysis}

Collected data were stored in NVivo 10 but analyzed manually using qualitative open and coaxial coding practices (Miles and Huberman, 1994). The transcripts from the first three cases 
iteratively fleshed out a coding scheme for different aspects of hybrid tensions and business model innovation. Additional codes were added to the coding scheme if they appeared in any subsequent transcript, and earlier transcripts were re-coded to reflect the new codes.

To enhance reliability, we revisited the data a week after the initial coding and verified the consistency of coding by summarizing coded data for each case, and each code categorization in table format. The tables were then cross-analyzed. This procedure resulted in minor modifications, which signals high reliability of initial data coding. A similar approach was then repeated for secondary data sources.

\subsection{Findings}

The entrepreneurs identified a series of common hybridity related tensions, caused by trying to balance the sustainability mission and economic value.

We generate too little impact, because we are generating too little volume... the mechanisms put in place are virtuous, they are good. That's all very well, but without volume, no impact. (Iota)

We are searching for the business case, but engaged in this idealistic point of view. It's a little bit chaotic.. (Kappa)

I find it very difficult, there's a tension. On the one hand, we really want to promote sustainability, but on the other hand if [customers] are quite happy to drink pesticides $\{$ shrugs\}! (Delta)

Interestingly the respondents focused mostly on tensions being driven by external interactions, which had an impact on internal decision-making, rather than having internal conflict caused by disagreements. One explanation for this is that the cases are all integrated hybrids, so social and environmental value creation was embedded in the products, processes and 
activities of the economic activity. Another explanation could be that the continued presence of the founding entrepreneurs has maintained a consistent sense of internal identity. Either way, we focus this findings section on the business model innovations utilized to minimize hybrid tensions driven by these external interactions. The purpose of this section is not provide an exhaustive list of tensions or innovations, because they may vary greatly over different hybrid forms. Instead, the focus is on how sustainable entrepreneurs develop a set of business model innovations which provide a stable platform for their activities, and ameliorate the consequence of hybridity related uncertainty. Table 3 provides examples of nine typical tensions identified in the sample, one for each of the sub-dimensions in Bocken et al.'s (2014) business model framework (excluding technology which is absorbed into other elements). Table 4 then presents nine business model innovations utilized to counteract these tensions. The tables and findings should be read as examples of tensions, and common elements of solutions through business model innovation, they do not represent the whole business model, nor idealized forms of business model. The following sections narrow this exploration further by presenting an expanded view of just three of these business model innovations, one for each of the core elements of the business model, to demonstrate the dominant narrative in the data regarding how integrating hybrid values in the business model ameliorates hybrid tension.

[Insert table 3 here]

[Insert table 4 here]

\subsubsection{Value propositions}

All the cases had similar problems with value propositions: The core product or service was more expensive than competitor offerings because of the costs associated with being more sustainable. This has implications for onward supply to distributers, but also on customer product 
perception. Every case commented on a lack of sustainable consumers willing to absorb this additional cost, meaning products had to be targeted at mainstream consumers who have limited interest in sustainability.

Pubs generally don't see the benefit of having local barley. They just want decent beer on the bar to sell. (Delta)

Customers just want great chocolate. If my chocolate is not great, they simply go elsewhere (Iota)

The organizations therefore needed to identify large enough target customer segments, who are willing to pay the associated price premium. Two common business models solutions emerge. Model one targets higher priced customer segments. This is achieved by marketing how the sustainability practices embedded in the product improve product quality, thus justifying the price (used by Alpha, Beta, Epsilon, Gamma, Iota, Theta, Zeta). Model two is giving the product exclusivity value by limiting supply, or customer choice, through distribution agreements (used by Delta, Eta, Iota, Theta, Epsilon and Kappa). Delta for instance will only supply its product within a 35mile radius commenting "People know us all around the country but we are hard to get hold of". They also have vegan beer, which is rare in the UK, and commands a price premium. Conversely Eta maintains exclusivity in the other meaning of the word; by having a number of agreements with outlets to only supply its products. Both models are successful for the different enterprises, and could also be used in combination. However the business model in each organization is geared towards integrating the sustainability value into the value proposition, either through perceived quality improvement, or as a means of negotiating exclusivity, thus ameliorating potential hybrid tensions.

\subsubsection{Value Creation and Delivery}


Continuing this theme, value creation and delivery have to be aligned with the value proposition. This includes providence of supply, access to finance, partner selection, and employee engagement (see tables 3 and 4). All of which have hybrid tensions attached. Here, however, we expand on respondents concerns regarding access to distribution, which is less well explored in literature. The entrepreneurs struggle with distribution for two reasons, one is a personal ethical problem with large retailers:

They are companies that make lots and lots of marketing noise with sustainable development, but it is only applied as part of the marketing... How can you sell products that follow a logic of sustainable development next to products that are hyper-pollutants; that put micro-particles everywhere? I do not understand this logic. (Zeta)

The second is the time and cost associated with dealing with independent retailers:

If you are working with a big retailer the product goes from a point of manufacture straight into a distribution center, so it's a one-stop-shop. If you are working with smaller independents, you sell to a wholesaler; wholesaler will sell to a distributor; distributor will sell to another local distributor who will then sell to a store. So you've got three or four layers of margin to be built into product costs before it comes to a little grocery store near you. (Eta)

The case studies approach their channel management in different ways to accommodate this. Alpha, Beta, Iota and Zeta predominantly sell through major retailers, despite ethical reservations. They are able to do this by manipulating their communications to present themselves as traditional, high end producers, and limit the discussion of their core sustainability. Particularly promoting the additional cash flow retailers make selling higher value produce. As 
discussed in section 1.4.1 some cases also negotiate exclusivity agreements with retailers to limit competitors. All ten cases however make use of a different, technological approach, which bypasses retailers: the internet.

Sustainable entrepreneurs have an edge over commercial entrepreneurs online, because you can always find people that agree with your ethics somewhere.

The market is more decentralized and everything we do is not like creating a big company, but going for decentralized structures in the sense that we try to position ourselves as a social movement. That vision that the world connects together ... That more grassroots, social movement type of marketing. (Kappa)

All the cases have a good web presence, e-commerce capability, and engage in sustainability discussion forums. The majority of marketing spend goes on social media. The cases are engaging customers actively in this space, having between 6,500-350,000 likes on Facebook (average 64,000, Eta being the biggest) and 3,600-24,000 followers on Twitter (average 8,300, Alpha being biggest). As this is a relational medium, it is viewed positively by respondents because it helps them to connect with likeminded consumers, and helps shape alternative social norms. It also builds a supporter base who lobby retailers for shelf-space, overcoming retailer restraint.

\subsubsection{Value Capture}

The most significant aspect in managing hybridity however, is linking economic value capture directly to improving sustainability. Much of the literature on hybridity presents the business activity as creating tension against the social or environmental mission. Although this may be true for differentiated hybrids; in integrated hybrids such as sustainable entrepreneurs, it would 
be a failure of the business model for them to be in direct conflict. The main tension found in value capture relates to how the cases distribute profits. Within all the cases there is an appreciation of the potential conflict between reinvesting into the business, through wages, marketing expenditure etc., and redistribution of profits to beneficiaries through support for producers, investment in lower impact technology etc.

For some such as Gamma and Kappa, just doing business fulfills their environmental missions: promoting urban farming, and sustainable menus respectively. For others such as Delta, Epsilon, Theta, and Gamma, the focus on geographic localities means they can follow slower, asset based scaling, without a need to grow commercially. Particularly for Delta, Gamma, and Kappa, their beneficiaries are also their customers, thus avoiding some tensions. Alpha, Beta, Eta, Zeta and Iota however have greater potential for mission drift due to their less direct link between customers and beneficiaries. However in each case integrated business models are built to avoid internal tension. Eta for instance stick explicitly to "we give away $100 \%$ of our profits" as a core element of their entire business model. They won't pay for marketing, take on debt which requires interest etc.. Indeed both Eta and Iota have structural separation, in that they donate all profits to a charitable trust which service beneficiaries under its own unique business model. Zeta similarly have an over-riding ethos which directs surplus: "the philosophy of cradle-to-cradle". All surplus is reinvested into delivering the most sustainable operations possible. We therefore see business model innovations removing the potential for hybridity derived tension through fixed architecture for dealing with potential issues.

\subsection{Discussion and Conclusion}

This paper integrates the literatures of hybrid entrepreneurs and sustainable business models, contributing to both fields. The discussion firstly explores the benefits of thinking in business 
model terms when dealing with hybridity related tensions, and secondly, explores the contribution of investigating sustainable entrepreneurs in the development of the sustainable business models literature.

\subsubsection{Contributions to hybridity}

The hybridity literature is dominated by the underlying assumption that hybridity manifests as tensions (Pache and Santos, 2013; Smith et al., 2013), and our cases could identify areas susceptible to hybrid tension. The focus of the hybridity literature to date has been identifying the areas of organizations in which hybrid tensions manifest, with limited exploration of the practicalities of how they are managed (Battilana and Lee, 2014; Doherty et al, 2014). This paper contributes a clear case for considering the business model, and business model innovations (as exampled in table 4) in addressing areas of hybrid tension. All the case entrepreneurs had business models designed to align value creation or make decision-making relatively straight forward when the multiple values had potential to conflict. The primary purpose of a business model is to balance diverse values into a holistic whole (Boons and Lüdeke-Freund, 2013). In the cases this was achieved either directly through the product-service system, or through governance policies, such as structural separation, which negate any need for negotiation. Even if this involved forgoing short-term growth opportunities; such as relying on asset based growth strategies, to maintain the integrity of the overall sustainable business model. The proposal which can be reached from this is that integrated hybrids should be able to deliver on holistic value creation, as per the sustainable business models literature (Lüdeke-Freund et al., 2017; Bocken et al., 2014). Differentiated hybrids may be more prone to tensions caused by having parallel business models, for commercial vs. social and environmental value creation, but this could be potentially be managed through structural separation. Two of our cases Eta and Iota 
separated governance for the societal impact and economic arms of the enterprise, but even here we see it is a hybridized business model because the economic value of one arm flows directly into the other for the creation of societal value. The danger would arise from hybrids attempting to manage unrelated parallel models such as in Gebauer et al.'s (2017) analysis of social enterprise SOIL, where each arm is competing for shared resources such as management time and financial investment as shown in Figure 1.

\section{[Insert figure 1 here]}

It was particularly noticeable that the sustainable entrepreneurs identified external interactions as the greatest source of hybrid tensions. Many people within the institutional environment struggle to inter-relate with hybrid organizations (Dey and Teasdale 2015; Pache and Santos, 2013). In the findings section only the customer and retailer related problems were expanded upon, but table 3 has a quotes relating to institutionalized problems in accessing finance, network and human capital acquisition, which were universal across the cases. Even here the business model provides options for approaching the market in non-traditional ways to ameliorate tension. Little research has investigated hybrid value propositions, but one option for solving these external issues was to mimic more traditional business model rhetoric when communicating externally (Dey and Teasdale 2015). This approach appears in many value propositions, resource acquisition, and channel management business models in our case studies. Other business model innovations also emerge such as making products more exclusive through supply agreements, or engaging communities in different ways through social media, and social movement marketing. Another approach involved embedding the organization in their communities as seen in a number of quotes in tables 3 and 4 . Whichever means was employed, other elements of the business model adjust to accommodate change, but still prove successful in 
alleviating the tensions as long as the business model remains holistic and hybridized across the organizations activities.

\subsubsection{Contributions to sustainable business models}

The main contribution of this paper is to provide theoretical and empirical clarity on the interplay between hybridity and sustainable business model innovation. The paper identifies that relatively similar sustainable entrepreneurs can experience hybridity heterogeneously. However, the emergence of common business model innovations to reduce the impact of these tensions was apparent, confirming that holistic business models are essential to the successful delivery of sustainability in business practice (Baumgartner and Ebner, 2010). As Schaltegger et al. (2012) suggests, the key challenge is in designing business models that allow economic value capture, whilst delivering social and environmental benefits. In sustainability focused entrepreneurs this is reversed: the key challenge is in maintaining economic value whilst increasing social or environmental value (Austin et al., 2006). Baumgartner and Ebner (2010) suggest such hybrid approaches can be good for business and society, but can be difficult to implement because they require significant effort to integrate the different forms of value capture. What sustainable business models literature can learn from sustainable entrepreneurs is that: where the different aspects of the triple bottom line are complementary, tensions between them can be negated. If, however, value capture in one sphere conflicts with value capture in another, there will be a period of business instability, until a business model innovation is implemented to ameliorate the cause of conflict - such as governance mechanisms for prioritizing one over the other. Attempting to treat the different forms of value capture as disparate and unrelated, as in differentiated hybrids, is going to be more susceptible to tension and mission drift (Battilana et al., 2012; Austin et al., 2006). 


\subsubsection{Implications and recommendations}

This study provides an original theoretical contribution through the normative and empirical

integration of hybridity and business models literature. We see a great deal of complementarity between them with business model innovations (such as those in table 4) playing a key role in alleviating the tensions inherent in creating multiple forms of value. The paper is one of a limited number to explore sustainable business models in organizations specifically designed to encompass economic, social and environmental value, and as such presents a clear empirical contribution to the continuance of this field. We identify a number of strategies hybrids can employ to mitigate hybrid tensions, and in particular provide a very rare empirical exploration of how value propositions are crafted and implemented in hybrid organizations. However there is a great deal more to learn in this domain. The sample for this study was somewhat homogeneous, and further studies should explore the extent to which a common business model architypes and strategies around governance, marketing, channel and supply management, can alleviate the tensions associated with multiple forms of value capture in practice. There also needs to be further study of the implications of mission challenging situations in hybrid organizations, and the processes and practices of leadership change. More pressingly however we need to understand the extent to which business models can be hybridized, and in what conditions we must accept parallel business models, and modes of managing these holistically.

\subsection{References}

Anner, M., 2012. Corporate social responsibility and freedom of association rights the precarious quest for legitimacy and control in global supply chains. Politics Soc. 40(4), 609-644.

Austin, J., Stevenson, H., Wei- Skillern, J., 2006. Social and commercial entrepreneurship: same, different, or both?. Entrep. Theory Pract, 30(1), 1-22.

Battilana, J., Dorado, S., 2010. Building sustainable hybrid organizations: The case of commercial microfinance organizations. Acad. of Manag. J., 53(6), 1419-1440. 
Battilana, J., Lee, M., Walker, J., Dorsey, C., 2012. In search of the hybrid ideal. Stanford Soc. Innov. Rev., 10(3), 51-55.

Battilana, J., Lee. M., 2014. Advancing research on hybrid organizing —insights from the study of social enterprises. Acad. Manag. Ann, 8, 397-441.

Baumgartner, R.J., Ebner, D., 2010. Corporate sustainability strategies: sustainability profiles and maturity levels. Sustain. Dev., 18(2), 76-89.

Baumgartner, R.J., 2009. Organizational culture and leadership: Preconditions for the development of a sustainable corporation. Sustain. Dev., 17(2), 102-113.

Bocken, N.M.P., Fil, A., Prabhu, J., 2016. Scaling up social businesses in developing markets. J. Clean. Prod. 139, 295-308.

Bocken, N.M.P., Short, S.W., Rana, P., Evans, S., 2014. A literature and practice review to develop sustainable business model archetypes. J. Clean. Prod. 65, 42-56.

Boons, F., Lüdeke-Freund, F., 2013. Business models for sustainable innovation: state-of-the-art and steps towards a research agenda. J. Clean. Prod., 45, 9-19.

Dacin, M.T., Dacin, P.A., Tracey, P. 2011. Social entrepreneurship: A critique and future directions. Organ. Sci., 22(5), 1203-1213.

Davies, I.A. Chambers, L., Haugh, H. 2017. Barriers to social enterprise growth. J. Small Bus. Manag.. Forthcoming.

Davies, I.A. Crane, A., 2010. Corporate social responsibility in small- and medium- size enterprises: investigating employee engagement in fair trade companies. Bus. Ethics: Eur. Rev., 19(2), 126-139.

Dean, T.J., McMullen, J.S., 2007. Toward a theory of sustainable entrepreneurship: Reducing environmental degradation through entrepreneurial action. J. Bus. Venturing, 22(1), 50-76.

Defourny, J. Nyssens, M., 2012. The EMES approach of social enterprises in a comparative perspective, Google Books

Dey, P., Teasdale, S., 2016. The tactical mimicry of social enterprise strategies: Acting 'as if' in the everyday life of third sector organizations. Organ., 23(4), 485-504.

DiMaggio, P. Powell, W.W., 1983. The iron cage revisited: Collective rationality and institutional isomorphism in organizational fields. Am. Soc. Rev., 48(2), 147-160.

Doherty, B., Haugh, H., Lyon, F., 2014. Social enterprises as hybrid organizations: A review and research agenda. Int. J. Manag. Rev. 16(4), 417-436

Ebrahim, A., Battilana, J., Mair, J., 2014. The governance of social enterprises: Mission drift and accountability challenges in hybrid organizations. Res. Organ. Beh., 34, 81-100. 
Eisenhardt, K. M., Graebner, M. E. 2007. Theory building from cases: opportunities and challenges. Acad. Manag. J., 50(1), 25-32.

European Commission 2017. Social Enterprises, Available at: http://ec.europa.eu/growth/sectors/social-economy/enterprises en, Accessed on 30/03/2017 at 10:15.

Gebauer, H., Gebauer, H., Saul, C., Saul, C., Halidmann, M., Halidmann, M., Kramer, S. and Kramer, S., 2017. When one business model is not enough for a social business. Strat. Direction, $33(1), 10-12$.

Grassl, W., 2012. Business models of social enterprise: A design approach to hybridity. ACRN J. Entrep. Perspect., 1 (1), 37-60.

Greenwood, R., Díaz, A.M., Li, S.X., Lorente, J.C. 2010. The multiplicity of institutional logics and the heterogeneity of organizational responses. Organ. Sci., 21 (2), 521-539.

Hahn, R. Ince, I., 2016. Constituents and characteristics of hybrid businesses: A qualitative, empirical framework. J. Small Bus. Manag., 54(1), 33-52.

Hall, J.K., Daneke, G.A. Lenox, M.J., 2010. Sustainable development and entrepreneurship: Past contributions and future directions. J. Bus. Venturing, 25(5), 439-448.

Jolink, A., Niesten, E., 2015. Sustainable development and business models of entrepreneurs in the organic food industry. Bus. Strat. Env., 24(6), 386-401.

Joyce, A. Paquin, R.L. 2016. The triple layered business model canvas: A tool to design more sustainable business models. J. Clean. Prod. 135, 1474-1486.

Lans, T., Blok, V., Wesselink, R., 2014. Learning apart and together: towards an integrated competence framework for sustainable entrepreneurship in higher education. J. Clean. Prod., 62, $37-47$.

Lehner, O.M., Nicholls, A., 2014. Social finance and crowdfunding for social enterprises: A public-private case study providing legitimacy and leverage. Venture Cap., 16(3), 271-286.

Lounsbury, M., Glynn, M.A., 2001. Cultural entrepreneurship: Stories, legitimacy, and the acquisition of resources. Strateg. Manag. J., 22(6- 7), 545-564.

Lüdeke-Freund, F., Freudenreich, B., Schaltegger, S., Saviuc, I. and Stock, M., 2017. Sustainability-Oriented Business Model Assessment-A Conceptual Foundation. In Analytics, Innovation, and Excellence-Driven Enterprise Sustainability (pp.169-206). Palgrave Macmillan US.

Margiono, A., Margiono, A., Zolin, R., Zolin, R., Chang, A. and Chang, A., 2017. A typology of social venture business model configurations. Int. J. Entrep. Beh. \& Res., Forthcoming

Miles, M.B., Huberman, A.M., 1994. Qualitative data analysis: An expanded sourcebook. Sage. 
Moss, T.W., Short, J.C., Payne, G., Tyge, Lumpkin, G.T. 2011. Dual identities in social ventures: An exploratory study. Entrep. Theory Prac., 35(4), 805-830.

Nicholls, A., 2010. The legitimacy of social entrepreneurship: reflexive isomorphism in a preparadigmatic field. Entrep. Theory Prac., 34(4), 611-633.

NMI (2015) LOHAS segmentation. Available at http://www.nmisolutions.com/index.php/syndicated-data/segmentation-algorithms-apanels/lohas-segmentation, Accessed on 15/03/2016 at 11:03.

Osterwalder, A., Pigneur, Y., 2010. business model generation: a handbook for visionaries, game changers, and challengers. John Wiley \& Sons, New Jersey.

Osterwalder, A., Pigneur, Y., Bernarda, G., Smith, A., 2014. Value proposition design: how to create products and services customers want. John Wiley \& Sons, New Jersey.

Osterwalder, A., Pigneur, Y., Tucci, C.L., 2005. Clarifying business models: origins, present, and future of the concept. Commun. Assoc. Inf. Sci. (CAIS) 16, 1-25.

Pache, A.C., Santos, F. 2013. Inside the hybrid organization: Selective coupling as a response to conflicting institutional logics. Acad. Manag. J., 56(4), 972-1001

Pache, A.C., Santos, F., 2010. When worlds collide: The internal dynamics of organizational responses to conflicting institutional demands. Acad. Manag. Rev., 35(3), 455-476.

Rauter, R., Jonker, J., Baumgartner, R.J., 2017. Going one's own way: drivers in developing business models for sustainability, J. Clean. Prod., 140(1), 144-154

Santos, F., Pache, A.C., Birkholz, C., 2015. Making hybrids work. Calif. Manag. Rev., 57(3), 3658.

Schaltegger, S., Lüdeke-Freund, F., Hansen, E.G., 2012. Business cases for sustainability: the role of business model innovation for corporate sustainability. Int. J. Innovat. Sustain. Dev. 6(2), 95-119.

Schaltegger, S., Lüdeke-Freund, F. Hansen, E.G., 2016. Business models for sustainability: a coevolutionary analysis of sustainable entrepreneurship, innovation, and transformation. Organ. Env., 29(3), 264-289.

Schaltegger, S., Wagner, M., 2011. Sustainable entrepreneurship and sustainability innovation: categories and interactions. Bus. Strat. Env. 20(4), 222-237.

Short, J.C., Moss, T.W., Lumpkin, G.T. 2009. Research in social entrepreneurship: Past contributions and future opportunities. Strateg. Entrep. J., 3(2), 161-194.

Smith, W.K., Gonin, M. Besharov, M.L., 2013. Managing social-business tensions: A review and research agenda for social enterprise. Bus. Ethic. Q., 23(3), 407-442. 
Teece, D., 2010. Business models, business strategy and innovation. Long Range Plan. 43(2-3), 172-194.

Wilson, F., Post, J.E., 2013. Business models for people, planet (\& profits): exploring the phenomena of social business, a market-based approach to social value creation. Small Bus. Econ., 40(3), 715-737.

Yin, R.K. 2003. Case study research: Design and methods ( $3^{\text {rd }}$ ed.). SAGE Publications, Inc. 
Figure 1: Levels of Value Integration in Sustainable Business Models

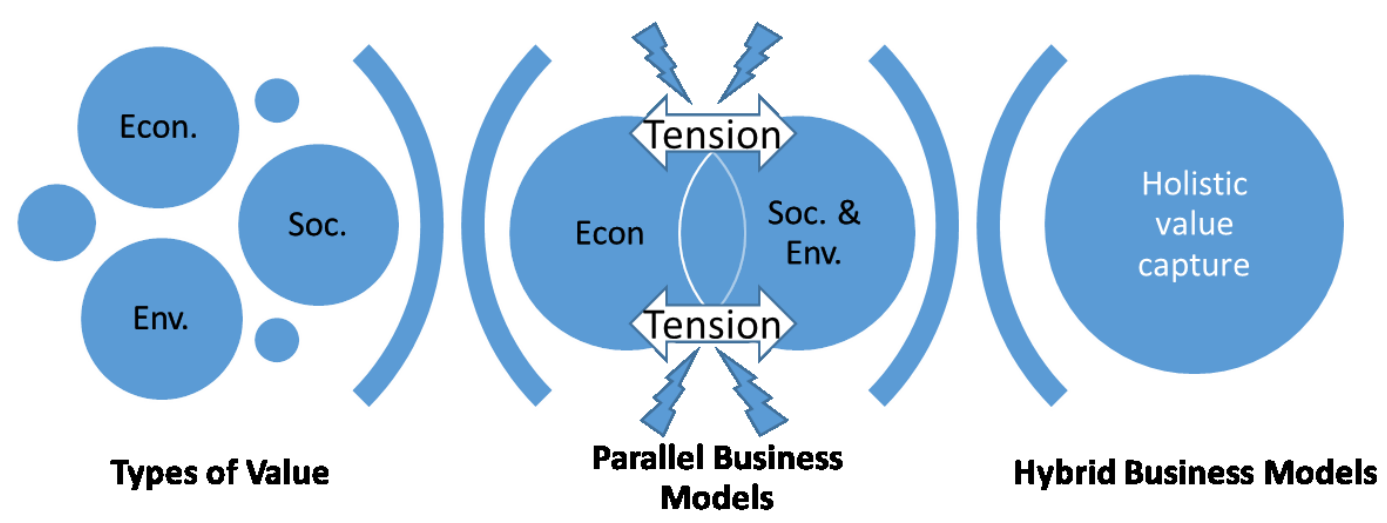


Table 1: Examples of Business Model Pillars in Hybridity Literature

\begin{tabular}{|c|c|c|c|c|c|}
\hline & Battilana \& Lee, 2013 & Dacin et al., 2011 & Doherty et al., 2014 & Hahn and Ince 2015 & Moss et al., 2011 \\
\hline $\begin{array}{l}\text { Value Proposition: } \\
\text { - } \quad \text { Product / service, } \\
\text { - } \quad \text { Customer segments, } \\
\text { - } \quad \text { Relationships }\end{array}$ & & Image & & $\begin{array}{l}\text { Underlying aims: } \\
\text { - Immaterial motives } \\
\text { - Transformation } \\
\text { orientation }\end{array}$ & $\begin{array}{l}\text { Product / service } \\
\text { Target Customer } \\
\text { Public Image } \\
\text { Proactiveness }\end{array}$ \\
\hline $\begin{array}{l}\text { Value creation and } \\
\text { Delivery: } \\
\text { - } \text { Activities, } \\
\text { - } \text { Resources, } \\
\text { - Channels, } \\
\text { - } \text { Partners, }\end{array}$ & $\begin{array}{l}\text { Organizational design } \\
\text { Resource } \\
\text { accumulation and } \\
\text { allocation } \\
\text { Workforce } \\
\text { composition } \\
\text { Inter-organizational } \\
\text { relationships }\end{array}$ & $\begin{array}{l}\text { Networks } \\
\text { Culture } \\
\text { Institutions and social } \\
\text { movements } \\
\text { Knowledge and } \\
\text { processing }\end{array}$ & $\begin{array}{l}\text { Stakeholder } \\
\text { mobilization } \\
\text { Human resources } \\
\text { mobilization } \\
\text { Financial resource } \\
\text { management } \\
\text { (financing) }\end{array}$ & $\begin{array}{l}\text { Organization: } \\
\text { - Participation } \\
\text { - Communication }\end{array}$ & $\begin{array}{l}\text { Geographic domain } \\
\text { Commonality } \\
\text { Competitive } \\
\text { aggressiveness } \\
\text { Innovativeness } \\
\text { Technology }\end{array}$ \\
\hline $\begin{array}{l}\text { Value capture: } \\
\text { - } \quad \text { Cost structure } \\
\text { - } \quad \text { Revenue streams }\end{array}$ & Revenue generation & & $\begin{array}{l}\text { Financial resource } \\
\text { management: } \\
\text { - } \text { Revenue generation } \\
\text { - Income streams }\end{array}$ & $\begin{array}{l}\text { Outcomes: } \\
\text { - } \text { General profit } \\
\text { orientation } \\
\text { - } \quad \text { Strategic } \\
\text { sustainable growth }\end{array}$ & Risk Taking \\
\hline
\end{tabular}


Table 2: Sample and case description

\begin{tabular}{|c|c|c|c|}
\hline Firm & Founded & $\begin{array}{c}\text { \# of employees (interview } \\
\text { participants) }\end{array}$ & Type of business \\
\hline Alpha & $\begin{array}{l}2006 \\
\text { UK }\end{array}$ & $9(3)$ & $\begin{array}{l}\text { Organic, all natural, and healthy cereals and } \\
\text { snacks, local buyers where possible, fairer } \\
\text { trading terms for growers }\end{array}$ \\
\hline Beta & $\begin{array}{c}2003 \\
\text { Switzerland }\end{array}$ & $3(3)$ & $\begin{array}{l}\text { Low Carbon, Organic, all natural smoothies, } \\
\text { supporting local farming groups }\end{array}$ \\
\hline Gamma & $\begin{array}{c}2010 \\
\text { Switzerland }\end{array}$ & $6(3)$ & $\begin{array}{l}\text { Co-operative, open innovation, rooftop } \\
\text { aquaponics agribusiness, developing } \\
\text { sustainable food technologies }\end{array}$ \\
\hline Delta & $\begin{array}{c}2006 \\
\text { UK }\end{array}$ & $6(2)$ & $\begin{array}{l}\text { Organic, locally funded, local sourced, local } \\
\text { supply brewery }\end{array}$ \\
\hline Epsilon & $\begin{array}{l}2006 \\
\text { France }\end{array}$ & $1(1)$ & $\begin{array}{l}\text { Ethically sourced and fair trade chocolates } \\
\text { promoting diversity and climate adaption in } \\
\text { growing communities }\end{array}$ \\
\hline Zeta & $\begin{array}{l}2006 \\
\text { Belgium }\end{array}$ & $2(2)$ & $\begin{array}{l}\text { Sustainably sourced, organic and healthy soft } \\
\text { drinks, lobbyists on sugar consumption, and } \\
\text { promote healthy lifestyles }\end{array}$ \\
\hline Eta & $\begin{array}{l}2004 \\
\text { UK }\end{array}$ & $20(2)$ & $\begin{array}{l}\text { Western consumables sold to fund projects } \\
\text { across sub-Saharan Africa (e.g. Bottle water } \\
\text { funds water pumps, Condoms fund HIV } \\
\text { prevention, Kitchen foil funds stoves etc.) }\end{array}$ \\
\hline Theta & $\begin{array}{c}2003 \\
\text { UK }\end{array}$ & $10(2)$ & $\begin{array}{l}\text { Sustainably produced organic, fair trade, wild- } \\
\text { grown coffee, supporting healthy rainforest } \\
\text { management }\end{array}$ \\
\hline Iota & $\begin{array}{l}2005 \\
\text { France }\end{array}$ & $10(1)$ & $\begin{array}{l}\text { Farmer owned social integration enterprise } \\
\text { producing fair trade chocolate, managing } \\
\text { climate change adaption }\end{array}$ \\
\hline Kappa & $\begin{array}{c}2009 \\
\text { Switzerland }\end{array}$ & $4(2)$ & $\begin{array}{l}\text { Food retail consultants on climate-friendly } \\
\text { menus and ethical sourcing }\end{array}$ \\
\hline
\end{tabular}


Table 3: Typical hybrid tensions

\begin{tabular}{|c|c|c|c|c|}
\hline Business Model Pillars & \multicolumn{3}{|c|}{ Typical Hybridity Tensions } & \multirow[b]{2}{*}{$\begin{array}{l}\text { Case Examples } \\
\text { It's more expensive than other products, of course, but there } \\
\text { is still a vast difference. Most products you find on the } \\
\text { market are water, sugar, and chemicals. Here you really } \\
\text { have tea made with real tea leaves, with fruit juice, and } \\
\text { there is a difference.(Zeta) } \\
\text { We are not successful enough in telling retailers the story } \\
\text { that we are independent, that we are local, that we are } \\
\text { organic because we are too small to make everybody } \\
\text { understand the difference.(Beta) } \\
\text { There is an integrity to our business around localism at a } \\
\text { certain scale. And once you grow beyond that, you lose that } \\
\text { integrity and you can no longer sell yourself on that } \\
\text { basis.(Delta) }\end{array}$} \\
\hline $\begin{array}{l}\text { Value Proposition: } \\
\text {-Product / service } \\
\text {-Customer segments } \\
\text {-Relationships }\end{array}$ & $\begin{array}{r}\text { Targeting niches of } \\
\text { sustainable consumers } \\
\text { Being a business in the } \\
\text { community }\end{array}$ & $\mathrm{v}$ & $\begin{array}{l}\text { Targeting mainstream } \\
\text { consumers } \\
\text { Being commercially focused }\end{array}$ & \\
\hline $\begin{array}{l}\text { Value creation and } \\
\text { Delivery: } \\
\text {-Activities } \\
\text {-Resources } \\
\text {-Channels } \\
\text {-Partners }\end{array}$ & $\begin{array}{r}\text { Sustainable sources of supply } \\
\text { Finance through "ethical" } \\
\text { sources } \\
\text { Distribution networks with } \\
\text { similar mission } \\
\text { Change the market with other } \\
\text { SEs }\end{array}$ & $\mathrm{v}$ & $\begin{array}{l}\text { Convenience and costs } \\
\text { Available and affordable } \\
\text { finance } \\
\text { Access to distribution } \\
\text { SEs are direct competitors }\end{array}$ & $\begin{array}{l}\text { So yes, we try to go to the printers and packaging printers } \\
\text { who are least damaging [on the environment]... But they are } \\
\text { hard to find and very expensive. (Iota) } \\
\text { [Banks] don't want us. They ask us, 'what is your business } \\
\text { concept? We don't understand, we cannot give you the } \\
\text { money because we don't understand this idea'.(Theta) } \\
\text { How do you convince [supermarkets] to put our water on } \\
\text { their shelves without paying a lot of money to do it?... [one] } \\
\text { asked us to pay a } £ 1.5 \text { million listing fee.(Eta) } \\
\text { I think a lot of potential competitors are also potential } \\
\text { partners.(Kappa) }\end{array}$ \\
\hline $\begin{array}{l}\text { Value capture: } \\
\text {-Cost structure } \\
\text {-Revenue streams }\end{array}$ & $\begin{array}{r}\text { Addressing social or } \\
\text { environmental problems } \\
\text { Distributing profit to } \\
\text { beneficiaries }\end{array}$ & $\mathrm{v}$ & $\begin{array}{l}\text { Creating revenue and self- } \\
\text { employment } \\
\text { Re-investing profit in } \\
\text { business dev., }\end{array}$ & $\begin{array}{l}\text { I might be willing to lose these profits in order to maintain } \\
\text { the integrity of the business.(Delta) } \\
\text { We have a commitment to give away } 100 \% \text { of the money } \\
\text { we make, so that's what we do.(Eta) }\end{array}$ \\
\hline
\end{tabular}


Table 4: Common Business Model Innovations

\begin{tabular}{|c|c|c|}
\hline Business Model Pillars & $\begin{array}{l}\text { Common Components of Business Model } \\
\text { Innovations }\end{array}$ & Case Examples \\
\hline $\begin{array}{l}\text { Value Proposition: } \\
\text {-Product / service } \\
\text {-Customer segments } \\
\text {-Relationships }\end{array}$ & $\begin{array}{l}\text { Promote how sustainability improves product quality } \\
\text { Target high quality focused customers that can bear a } \\
\text { higher price } \\
\text { Engage multiple stakeholders in developing an } \\
\text { emotional stake in the enterprise }\end{array}$ & $\begin{array}{l}\text { If we focus on making the values really clear, so that the people who } \\
\text { were interested knew that we were front of mind.(Alpha) } \\
\text { We are trying to maintain certain exclusivity by not selling through the } \\
\text { supermarkets or by being of a certain scale. So even for our regular } \\
\text { beers, you know, we want to develop a reputation.(Delta) } \\
\text { [Eta] has already struck a chord with consumers in the UK, Australia } \\
\text { and the US, not only because, as a company, it genuinely lives and } \\
\text { breathes the ethics and ethos of its products, but also because people } \\
\text { want to make a difference, one small step at a time.(news excerpt) }\end{array}$ \\
\hline $\begin{array}{l}\text { Value creation and } \\
\text { Delivery: } \\
\text {-Activities } \\
\text {-Resources } \\
\text {-Channels } \\
\text {-Partners }\end{array}$ & $\begin{array}{l}\text { Ethics of business activities are negotiable, but certain } \\
\text { activities are "ring fenced" to ensure sustainability. } \\
\text { Resource shortages can be overcome through } \\
\text { exploiting sustainability in partners } \\
\text { Reducing proximity between customers and the SE } \\
\text { can subvert traditional channel chains } \\
\text { Working collaboratively with like-minded competitors } \\
\text { gives the impression of size and negotiation power }\end{array}$ & $\begin{array}{l}\text { [A bank loan] is not what we really wanted but we couldn't have } \\
\text { continued to grow without it, but the rest of the businesses } \\
\text { values are maintained.(Zeta) } \\
\text { We call it an integrated project because all possible NGOs, partners, } \\
\text { initiatives are integrated to help the region, to develop the region, to } \\
\text { support the people there.(Theta) } \\
\text { When you don't have any money to engage in above the line } \\
\text { spend in advertising and promotion, you've got to use your } \\
\text { imagination which is free, and the channel to use that } \\
\text { imagination is digital.(Alpha) } \\
\text { Now it's time for entrepreneurs around the world to [use our } \\
\text { technology] to expand this reality and bring a fresh revolution } \\
\text { into our cities, one fish and one tomato at a time.(Gamma) }\end{array}$ \\
\hline $\begin{array}{l}\text { Value capture: } \\
\text {-Cost structure } \\
\text {-Revenue streams }\end{array}$ & $\begin{array}{l}\text { Follow low debt, slow, asset based growth strategies } \\
\text { Linking sustainable impact directly to commercial } \\
\text { success. }\end{array}$ & $\begin{array}{l}\text { You might talk to a lot of businesses and they will all talk about } \\
\text { continued growth and that's not our ambition at all... if we can } \\
\text { be brewing four times a week and supporting our team of six } \\
\text { people, that is our end strategy.(Delta) } \\
\text { The idea was to try and create this like-for-like concept of water } \\
\text { funding water projects. But, if we could make that work, could } \\
\text { we then replicate it in other products. So toilet tissues fund } \\
\text { sanitation programmes, soap funds hygiene, condoms funds } \\
\text { HIV... food products fund food and so on and so forth.(Eta) }\end{array}$ \\
\hline
\end{tabular}

